\title{
Academic achievement in Norwegian secondary schools: the impact of violence during childhood
}

\author{
Lihong Huang • Svein Mossige
}

Received: 24 February 2011 / Accepted: 1 November 2011 / Published online: 13 December 2011

(C) The Author(s) 2011. This article is published with open access at Springerlink.com

\begin{abstract}
Using data from a national survey $(\mathrm{N}=6,979)$ of young people in their last year in Norwegian secondary schools in 2007 (aged 18 and 19), this paper examines the effect of experience of violence including sexual abuse during childhood (before the age of 13) on the later academic achievement of young people. This investigation includes three types of violence: non-physical, physical and sexual, and two types of victimisation: being abused and witness to abuse. First we investigate the relationship between the experience of various violent acts before the age of 13 and young people's later academic achievement. Second, applying the structural equation modelling technique, we take into account the effect of background factors such as parents' educational attainment and gender, and the effect of mediating factors such as social capital and educational motivation on the academic achievement of the young victims. The results show that exposure to violence during childhood not only directly influences young people's educational outcomes but also exerts indirect influences on their achievement through its impact on young victims' social relations and psychological health.
\end{abstract}

Keywords Academic achievement - Violence and sexual abuse against children . Family socio-economic status · Social capital · Psychological health ·

Structural equation modelling (LISREL)

L. Huang ( $ه)$

NOVA, Norwegian Social Research, Postbox 3223, 0208 Elisenberg, Oslo, Norway

e-mail: lihong.huang@nova.no

S. Mossige

Department of Psychology, University of Oslo, Postbox 1094, 0317 Blindern, Oslo, Norway

e-mail: sveinmos@psykologi.uio.no 


\section{Introduction}

According to Article 19 of the UN Convention on the Rights of the Child, the definition of violence is "all forms of physical or mental violence, injury and abuse, neglect or negligent treatment, maltreatment or exploitation, including sexual abuse". According to the definition of the World Health Organisation (WHO), child abuse "includes all forms of physical and emotional ill-treatment, sexual abuse, neglect and exploitation that results in actual or potential harm to the child's health, development or dignity in the context of a relationship of responsibility, trust or power" (WHO 2006: 9). Since the 1990s, many countries across the world have become more aware of the serious existence of violence against children. Approximately $20 \%$ of women and 5-10\% of men report being sexually abused as children while $25-50 \%$ of children report being physically abused (WHO 2010). In high income countries such as Australia, Canada, USA and UK, every year, about $4-16 \%$ of children are physically abused, one in ten is neglected or psychologically abused, and 5-10\% of boys and girls are exposed to penetrative sexual abuse, whilst up to three times this number are exposed to other forms of sexual abuse (Gilbert et al. 2009). In the five countries of the Baltic Sea region (Estonia, Lithuania, Norway, Poland and Sweden), 20-50\% of girls and 10-25\% of the boys at the age of 18 report to have experienced some type of sexual abuse (Mossige et al. 2007; Kjellgren et al. 2009; Seto et al. 2010).

Several major national and international investigations and research projects in the US (Fromm 2001), in Canada (Trocmé et al. 2001), in Norway (Mossige and Stefansen 2007), in the Baltic Sea Region (Mossige et al. 2007), and in the world (Pinheiro 2006) have focused on the prevalence and the consequence of child maltreatment, seeking prevention and intervention strategies mainly from the perspectives of epidemiology, psychology and human rights. Furthermore, previous research has established that exposure to violence and sexual abuse during childhood causes both short- and longterm damage not only in terms of the physical, psychological and social development of the child (Macmillan 2001) but also upon his/her school performance and educational achievement (Fergusson and Mullen 1999; Veltman and Browne 2001; Daignault and Hebert 2004; Cicchetti and Toth 2005; Boden et al. 2007). Nevertheless, data and methodological limitations can be found in previous studies that have investigated the effect of child abuse on school performance and educational achievement (Boden et al. 2007) where contextual factors and individual factors have not been sufficiently controlled for in detecting the long-term effects of child abuse (Kawachi and Subramanian 2006).

This study investigates the effect of exposure to violence and sexual abuse during childhood upon the later academic achievement of young victims, using data from a national survey $(\mathrm{N}=6,979)$ of young people in their final year in Norwegian secondary school in 2007 (aged 18 and 19). After reviewing relevant theories and previous research, we introduce the data and measures applied in this study. We analyse the data with an analytical framework built on theories of social stratification, social psychology, social capital and findings from previous research. Besides controlling for the effects of home background, and individual characteristics, we investigate the effect of child abuse by taking into consideration contextual factors at home and in the school environment where personal interactions take place and relationships are forged. 


\section{Academic achievement and the influential factors}

The persistent influence of home socio-economic background on an individual's educational outcome and his/her eventual occupational attainment has been well established in sociological research since the 1970s (Husén 1989; Erikson and Jonsson 1998; Buru-Bellat 2004). The education systems were once often blamed as the institution which reproduced social inequality in our modern societies. In the last 20 years, however, sociological, psychological and pedagogical research results have shown that many factors, such as structures, resources, norms, environments and social relations at home and school, motivation and the psychological health of the child also influence school outcomes (Meier 1999; Parcel and Dufur 2001; Lee and Burkam 2003; Olsen 2003; Güzel and Berberoglu 2005: Sandefur et al. 2006; Huang 2009; Downes 2008, 2010). Of these various factors, home background has been found to be statistically more influential than school effects (Thrupp 1999; Breen and Jonsson 2005) while social relations and the psychological health of the child have increasingly received research attention for their unique and significant contribution to the school outcomes of children.

Figure 1 illustrates the conceptual and analytical framework of this study. This framework rests first on the sociological assumption that home background such as socio-economic status of the parents, and ethnicity and personal characteristics such as gender, have a direct influence upon school outcome variables such as academic achievement and future educational attainment (Husén 1989; Erikson and Jonsson 1998; Buru-Bellat 2004). The second assumption of the framework is based on social psychological research findings that victimisation by violence and sexual abuse during childhood inevitably influence subsequent social relations (Kawachi and Subramanian 2006; Constantinos et al. 2007; Georgiou and Fanti 2010), psychological health (Fergusson and Mullen 1999; Cicchetti and Toth 2005; Raskauskas 2010) and eventually the school outcomes of the child at a later stage of his/her life (Veltman and Browne 2001; Daignault and Hebert 2004; Boden et al. 2007).

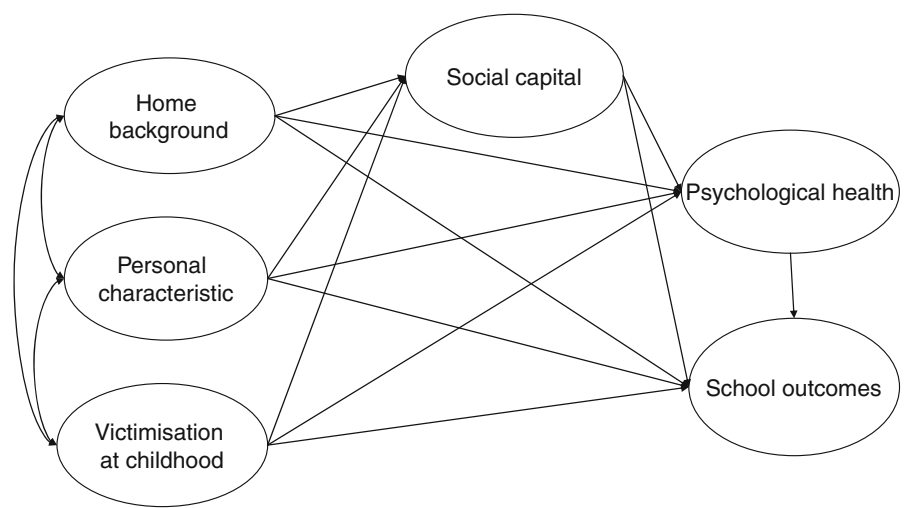

Fig. 1 Path diagram for a conceptual framework linking young peoples' home background, personal characteristics and victimisation at an earlier age with social capital, psychological health and academic achievement 
The third assumption of the framework is based on social capital theory that social capital of the child, influenced by the home background and abuse experiences at an earlier age, has a direct effect on his/her school achievement. Previous research applying the theory of social capital in an educational context, has found that home background factors, personal characteristics and experiences in childhood have direct influence on the social relations of the child (Astone et al. 1999). Good quality relationships within the family can lead to parental involvement in and assistance with their child's schooling (Coleman 1988; Sandefur et al. 2006; Teachman et al. 1996). Relationships with teachers can provide access to information and opportunities that enhance the educational performance of children (Huang 2008, 2009). However, previous research has also found that the relationships with friends and peers sometimes can be detrimental for the child's school career (Stanton-Salazar and Dornbusch 1995; Pijl and Frostad 2010; Huang 2010).

\section{Data and methods}

\subsection{Sample}

Data used in this study are from the Norwegian national youth survey, 'Youth survey on violence and abuse (LUVO)' conducted in 2007. The aim of the survey was to assess the prevalence of three different offences against children and youth: violence from parents to the child, witnessing violence against parents and experiences of sexual abuse (Mossige and Stefansen 2007). Seven throusand and thirty three students in their last year of education from 67 randomly selected upper secondary schools participated in the survey. Research permission was first obtained from authorities at the municipality level and at the school level. The students were given and two hours during a school day to answer the questionnaire. The response rate was $77 \%$. Data are based on responses of 6,979 students. Most of the respondents $(92 \%)$ were between ages 18-19 and 58\% of them were female. In this study, we categorise three types of offences against children: non-physical (severe verbal bullying or threat of violence), physical (slap with open hands, fists or beaten up) and sexual (touching, exposing or sexual acts), two types of young victims (being abused and being a witness of abuse), and two types of perpetrators (the parents and peers).

As a national youth survey, the data have a few limitations with regards to the estimations and interpretations of the prevalence and consequences of child abuse in Norway. First, as it was a school based survey, the sample under-represented (or even excluded) three groups of young people in Norway: (1) $2 \%$ of Norwegian young people who, upon completion of 10 years compulsory education, did not take up the offer of mandatory entry into 3 years upper secondary schooling; (2) over $30 \%$ of young people who drop out from schools between the first year and the last year of their upper secondary education (Markussen et al. 2008); and (3) male students who are overrepresented in vocational courses at upper secondary schools and were on field practice at the time of the survey (Mossige and Stefansen 2007). Second, although several measures were taken to assure the respondents both confidentiality and support for psychological counselling in answering such sensitive questions, researchers feared 
under-reporting due to the above mentioned under-represented groups and suppressed memory or memory loss of childhood abusive experiences when the correspondents were asked to recall events from their childhood (Mossige and Stefansen 2007).

\subsection{Measures}

Table 1 presents the measures applied for categorising victims. Each category of victims sums up the response items listed accordingly in the table. Table 1 also provides the number of cases in each category of abuses and the percentage of each category corresponding to the whole sample.

The measures presented in Table 1 are a result of deliberate categorisation of the survey data. For example, in the category of non-physical abuse, we exclude items such as teasing, shouting, or swearing as we consider them too mild to be labelled as abuse although they can be construed as a form of bullying. Factor analysis of the victim categories reflects a pattern of abuses which follows the types of perpetrator rather than types of abuses. Observing the cross loadings informs us that there are correlations among the abuses, especially among the 'in family' abuses such as 'Witness to parents being abused', 'abused by father' and 'abused by mother', while the differentiation between mild and heavy physical abuses is only shown in abuses by mother. Moreover, the data show that non-physical and physical abuses are rather strongly correlated. However, only the differentiations between abuses which happened before and after the age of 13 are further addressed in the analysis of whether and to what extent earlier experience of various abuses influences the academic achievement of young people.

Among the background variables, 'Parents live together' is measured by parents' civil status by combining categories of 'married' and 'cohabitation' as ' 1 ', else as ' 0 '. 'Parents with higher education' is measured by educational attainment by neither (as ' 0 '), one (as ' 1 ') or both (as ' 2 ') of the parents at tertiary level. 'Parents own the house they live in' is a dummy variable derived from a question concerned with whether parents own or rent the place they have lived for the past 5 years. 'Both parents work full time' is a dummy variable derived from a question asking if father and mother are working full time, part-time or not working. 'Parents take social welfare' is measured by neither (as ' 0 '), one (as ' 1 ') or both (as ' 2 ') of the parents in the past 2 years having taken any of the three types of social welfare: social assistance, disability insurance and unemployment payment. Home economy is a subjective measure by asking the correspondent 'Have your family had a good or bad economic situation in the past 2 years' on a six point scale (from ' 1 ' as a lot ups and downs, '2' as bad economy all the time, ' 3 ' as bad economy most of the time, '4' as neither good or bad, '5' as good economy most of time, ' 6 ' as good economy all the time). 'Bad home economy' is a combination of points ' 1 ', ' 2 ' and ' 3 '.

In the LUVO survey, the correspondent is asked to place the birth country of his/her father and mother among seven choices: Norway, another Nordic country, another European country, Asia, Africa, South America and North America. 'Both parents immigrants' is a combination of father's and mother's birth place in other countries than Norway and any other Nordic country. As shown in crosstab analysis, all the 
Table 1 Measures of abuses and victims

\begin{tabular}{|c|c|c|c|}
\hline Type of abuse & $\begin{array}{l}\text { Category of } \\
\text { victims }\end{array}$ & Measuring items & $\mathrm{N}(\%)$ \\
\hline \multirow[t]{3}{*}{ Non- physical abuses } & By peers & $\begin{array}{l}\text { 1. Been seriously bullied by peers } \\
\text { during/before the past } 12 \text { months, } \\
\text { the frequencies of such incidence } \\
\text { 2. Been sexually harassed by peers } \\
\text { during/before the past } 12 \text { months, } \\
\text { the frequencies of such incidence } \\
\text { 3. Been threatened with violence by } \\
\text { peers during/before the past } 12 \\
\text { months, the frequencies of such } \\
\text { incidence }\end{array}$ & $2,095(30 \%)$ \\
\hline & By parents & $\begin{array}{l}\text { 1. Before/after you were age } 13 \text {, had } \\
\text { your mother/father thrown/hit/kick } \\
\text { something during an argument } \\
\text { with you, the frequencies of such } \\
\text { incidence } \\
\text { 2. Before/after you were age } 13 \text {, had } \\
\text { your mother/father threatened you } \\
\text { with violence during an argument } \\
\text { with you, the frequencies of such } \\
\text { incidence }\end{array}$ & $1,075(15.4 \%)$ \\
\hline & $\begin{array}{r}\text { Witness parents } \\
\text { being abused }\end{array}$ & $\begin{array}{l}\text { 1. During/before the past } 12 \text { months, } \\
\text { have you seen or heard your } \\
\text { mother/father been abused, the } \\
\text { frequencies of such incidence } \\
\text { 2. During/before the past } 12 \text { months, } \\
\text { have you seen or heard your } \\
\text { mother/father been insulted or } \\
\text { humiliated, the frequencies of such } \\
\text { incidence } \\
\text { 3. During/before the past } 12 \text { months, } \\
\text { have you seen or heard your } \\
\text { mother/father been threatened with } \\
\text { violence, the frequencies of such } \\
\text { incidence }\end{array}$ & $2,453(35.1 \%)$ \\
\hline \multirow[t]{2}{*}{ Physical abuse } & By peers & $\begin{array}{l}\text { 1. Been injured by violence } \\
\text { perpetrated by peers whom } \\
\text { you knew from before } \\
\text { 2. Been injured by violence } \\
\text { perpetrated by peers who } \\
\text { were strangers to you }\end{array}$ & $1,400(20.1 \%)$ \\
\hline & By parents & $\begin{array}{l}\text { 1. Before/after you were age } 13 \text {, had } \\
\text { your mother/father pushed or } \\
\text { heavily shaken you during an } \\
\text { argument, the frequencies of such } \\
\text { incidence } \\
\text { 2. Before/after you were age } 13 \text {, had } \\
\text { your mother/father pulled your } \\
\text { hair or pinched you during an } \\
\text { argument, the frequencies of such } \\
\text { incidence }\end{array}$ & $1,841(26.4 \%)$ \\
\hline
\end{tabular}


Table 1 continued

\begin{tabular}{|c|c|c|c|}
\hline Type of abuse & $\begin{array}{l}\text { Category of } \\
\text { victims }\end{array}$ & Measuring items & $\mathrm{N}(\%)$ \\
\hline & $\begin{array}{r}\text { Witness parents } \\
\text { being abused }\end{array}$ & 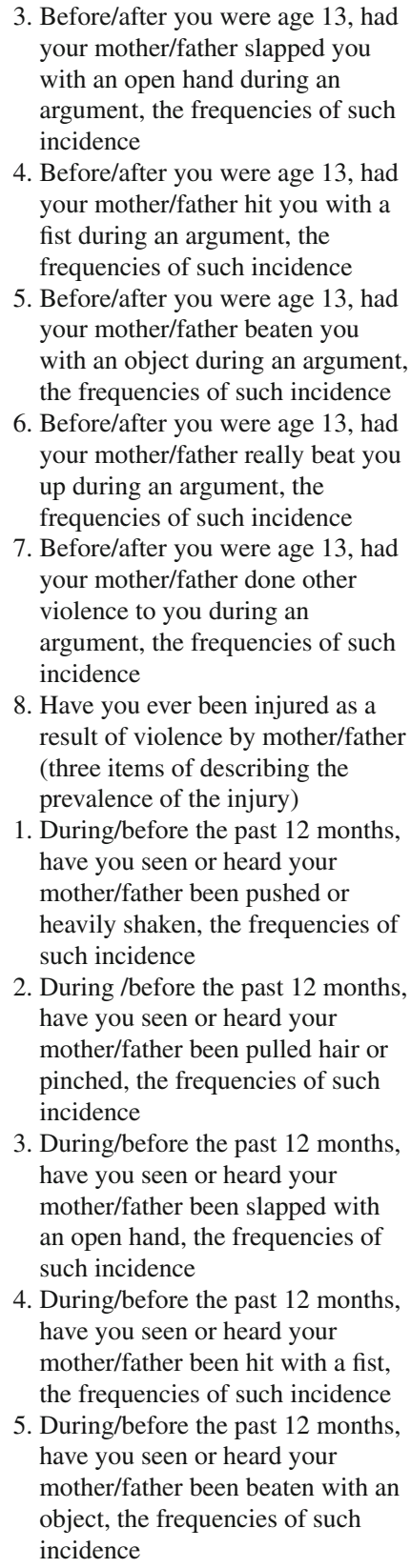 & $846(12.1 \%)$ \\
\hline
\end{tabular}


Table 1 continued

\begin{tabular}{|c|c|c|c|}
\hline Type of abuse & $\begin{array}{l}\text { Category of } \\
\text { victims }\end{array}$ & Measuring items & $\mathrm{N}(\%)$ \\
\hline Sexual abuse & Sexual abuse & 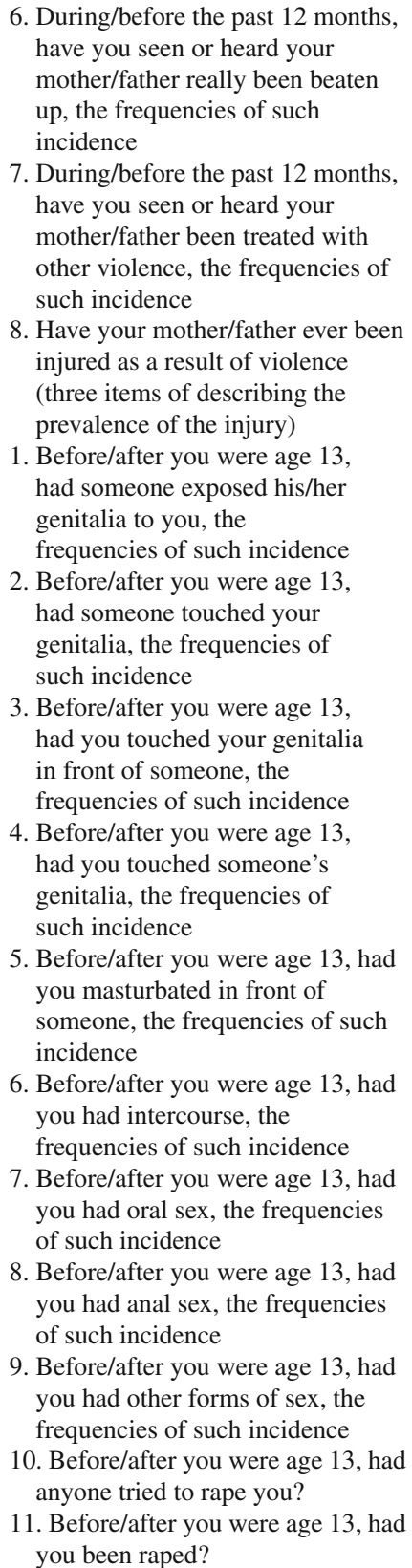 & $1,869(26.8 \%)$ \\
\hline
\end{tabular}


Table 2 Factor loadings of young people's social relation variables

\begin{tabular}{|c|c|c|c|}
\hline & Close relations & Good child-parents relations & Peer Friendship \\
\hline $\begin{array}{l}\text { I have close friends/family members } \\
\text { who really care about me }\end{array}$ & 0.858 & 0.101 & 0.117 \\
\hline $\begin{array}{l}\text { I have close friends/family members } \\
\text { who really appreciate my } \\
\text { personality }\end{array}$ & 0.838 & 0.159 & 0.160 \\
\hline $\begin{array}{l}\text { I have close friends/family members } \\
\text { who always encourage me }\end{array}$ & 0.809 & 0.174 & 0.098 \\
\hline In my family we support each other & 0.791 & 0.290 & 0.070 \\
\hline $\begin{array}{l}\text { My parents like me to make my own } \\
\text { decisions }\end{array}$ & 0.102 & 0.777 & 0.117 \\
\hline $\begin{array}{l}\text { My parents let me make my own } \\
\text { choices }\end{array}$ & 0.010 & 0.747 & 0.117 \\
\hline $\begin{array}{l}\text { My parents understand my problems } \\
\text { and worries }\end{array}$ & 0.306 & 0.638 & -0.023 \\
\hline $\begin{array}{l}\text { My parents are very loving towards } \\
\text { me }\end{array}$ & 0.326 & 0.620 & -0.028 \\
\hline Number of friends I have & 0.016 & 0.011 & 0.868 \\
\hline $\begin{array}{l}\text { Number of friends I have whom I can } \\
\text { trust with my secrets }\end{array}$ & 0.257 & 0.121 & 0.613 \\
\hline
\end{tabular}

Rotation method: Varimax with Kaiser Normalisation. Variance explained: 63\%

victim groups seem to be over represented in disadvantaged families compared with the whole sample. The group of 'witness to parents being physically abused' is the 'worst-off' by all indicators.

Questions and answers used to extract young people's social capital are from 40 items from three questions. The first question uses the Parent Bonding Instrument of Parker et al. (1979) with 11 items on four-point scales asking young people to describe their experiences of their parents. The second question uses the Resilience Scale for Adolescents (READ) (Hjemdal et al. 2006; Von Soest et al. 2010) with 27 items on five-point scales asking young people how they think or feel about themselves and the important people in their lives. The third question asks young people to provide the number of friends in two categories: friends they just hang around with and friends they can trust with their secrets. Exploratory factor analysis was used in the early stage of searching for variables that appear to measure distinct latent factors of young people's social capital. Table 2 presents the loadings of three relationship factors extracted from the data. Each factor is assigned a meaningful name with Factor 1 called 'close relations' as it seems to catch the mixing of friends and family members, Factor 2 called 'good child-parent relations', and Factor 3 called 'peer friendship'.

Questions in the LUVO dataset measuring the current psychological health of the young people includes first 12 items on a four-point scale from ' 0 ' as 'not be troubled at all', ' 1 ' as 'be little troubled' to ' 3 ' as 'be very much troubled' indicating various symptoms of depression and anxiety. Second, there are five items on a three-point scale from ' 0 ' as 'never happened', ' 1 ' as 'once happened', and '2' as 'happened several times' measuring self harming behaviours such as (1) taking an overdose on purpose, (2) trying to injure oneself, (3) attempted suicide, (4) been hospitalised due 
to self harming, and (5) been hospitalised due to attempted suicide. By summing up the items and taking the averages, we get three mean scores of psychological health, i.e. depression, anxiety and self harming, which are highly correlated. Regarding educational outcome variables, the data contain information on student achievement in mathematics, Norwegian and English, graded from lowest at ' 1 ' to highest at ' 6 '. Students' future educational plans were measured by responses to three response choices: education not beyond upper secondary school (which is the level at which the correspondents were attending at the moment of the survey), higher education at the basic level (as bachelor degree studies) and higher education at master degree level or higher.

\subsection{Analysing methods}

The first phase of the data analysis focuses on description of the variables that describe individual characteristics of the various victims compared with that of the non-abuse victims, which had been partially done in the previous section when measures of the study were introduced. In particular, multiple regression is used in analysing the general effect of various violence experiences on the educational achievement of the young people when home background variables and personal characteristics are controlled for.

The second phase of data analysis focuses on testing an operational model corresponding to the conceptual framework of this study, as an attempt to assess the long term effect of violence during childhood (that this panel dataset allows us to do) by applying structural equation modelling methods (LISREL). A structural equation model measures the contributions of various factors in predicting a particular outcome while providing unique information about the direct and indirect paths of influence (Mueller 1996; Ransdell 2001; Ransdell et al. 2001). LISREL allows for the simultaneous utilisation of a measurement model and a structural equation model. LISREL also allows the use of one or more directly measured or manifest variables (e.g. in our case, the variables of social capital) to provide estimates and simultaneously test the effects of the latent variables on one another. Other advantages of using LISREL modelling include the strength in estimating the unknown coefficients of a set of linear structural equations, the treatment of measurement errors, and the ability to consider simultaneity and/or interdependence.

The reporting procedure of model test results follows standards established in previous research in social sciences. According to a classification of standardised regression weights (Desjardins 2003) in social science research using population sample survey data, a regression weight over 0.30 is considered a very strong effect, from 0.20 to 0.30 is a strong effect, from 0.10 to 0.20 is a moderate effect and below 0.10 is a weak effect. The decision to accept or reject a hypothesised structural model is taken with reference to the fit statistics. Chi-square $\left(\chi^{2}\right)$ is most frequently cited as a measure of the overall goodness of fit of the model to the data (Jöreskog and Sörbom 1993). The Root Mean Square Residual (RMR) represents the average deviation of the predicted from the actual correlation matrix. The Goodness-of-fit Index (GFI) indicates the proportion of the joint amount of data variance and covariance that can be explained by 
the tested model. The common rule for an acceptable fit of a model is an RMR below 0.05, with AGFI (Adjusted Good-of-fit Index) and GFI exceeding 0.90 (Hoyle and Pantere 1995; Tuijnman and Keeves 1997).

\section{Results}

Figure 2 is a visual presentation of the descriptive statistics of educational plans and academic achievement of the young victims. It shows that young victim groups are not clearly singled out in terms of their average achievement. The young victims, however, are slightly over represented amongst the low achievers; and in particular those who suffer physical violence from their peers stand out as low achievers with low educational ambitions.

Before conducting multiple regression analysis, a correlation analysis between the various violence experiences and achievement is performed to eliminate variables that are not correlated with achievement. 'Witness to parents being non-physically abused' has no significant correlation with achievement and therefore is not included in the regression analysis. Table 3 presents the result of the regression in which Model 1 estimates the effect of abuse experiences on the sum of three test scores, Model 2 estimates the effect of abuse experiences controlling for various background variables, and Model 3 is Model 2 tested for girls and boys separately. As demonstrated in Table 3 , being physically abused by peers and exposure to sexual abuse both have strong negative effects on achievement. Although peer bullying is a serious problem in schools throughout the world, which contributes to serious psychological and social problems for the victims (Smith et al. 1999; Parada 2006), non-physical abuses by peers have no statistically significant influence on achievement. Meanwhile, the effect of physical abuse by parents disappeared when background variables were controlled. The influences of peer violence and sexual abuse are persistent when the background

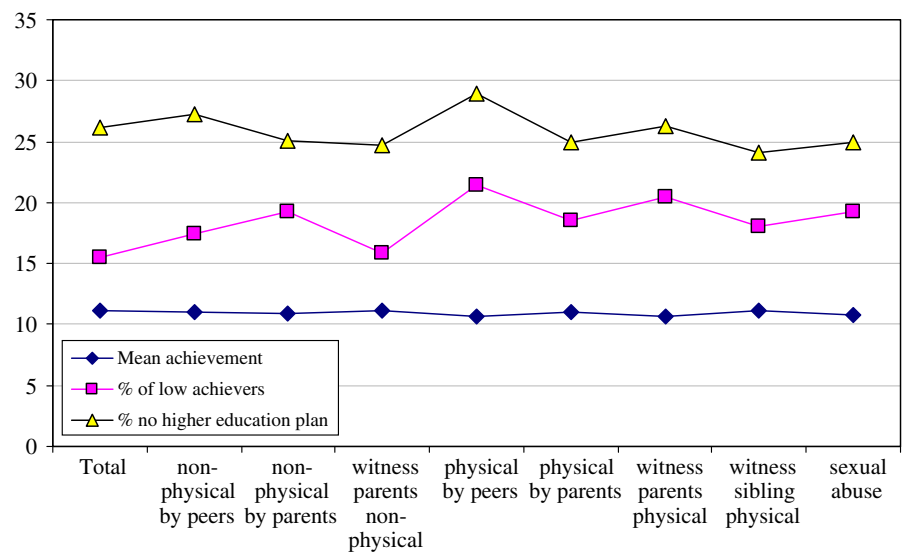

Fig. 2 Educational plan and achievement of the young victims. Note: 'Mean achievement' is the average of the sum grade of three subjects (English, Norwegian and Mathematics) by treating missing values as ' 0 '. 'Low achievers' are those whose sum achievement is 1 standardised deviation below the group mean 
Table 3 Multiple regression of experiences of abuse on academic achievement (sum of test scores of the three subjects)

\begin{tabular}{|c|c|c|c|c|}
\hline & Model 1 & Model 2 & Model 3: Girls & Model 3: Boys \\
\hline (Constant) & $11.50(0.05)^{* *}$ & $9.81(0.19)^{* *}$ & $9.76(0.24)^{* *}$ & $9.95(0.32)^{* *}$ \\
\hline $\begin{array}{l}\text { Non-physical } \\
\text { abuse by peers }\end{array}$ & $0.07(0.08)$ & $0.06(0.08)$ & $0.05(0.11)$ & $0.13(0.12)$ \\
\hline $\begin{array}{l}\text { Physical abuse by } \\
\text { peers }\end{array}$ & $-0.55(0.07)^{* *}$ & $-0.51(0.07)^{* *}$ & $-0.54(0.10)^{* *}$ & $-0.42(0.10)^{* *}$ \\
\hline $\begin{array}{l}\text { Non-physical } \\
\text { abuse by parents } \\
\text { before and after } \\
\text { age } 13\end{array}$ & $-0.04(0.09)$ & $-0.02(0.08)$ & $-0.05(0.11)$ & $0.05(0.13)$ \\
\hline $\begin{array}{l}\text { Physical abuse by } \\
\text { parents before } \\
\text { and after age } 13\end{array}$ & $-0.11(0.07) *$ & $-0.06(0.06)$ & $-0.03(0.08)$ & $-0.13(0.10)$ \\
\hline $\begin{array}{l}\text { Witness parents } \\
\text { being physically } \\
\text { abused }\end{array}$ & $-0.22(0.07)^{* *}$ & $-0.08(0.07)$ & $-0.06(0.08)$ & $-0.17(0.12)$ \\
\hline $\begin{array}{l}\text { Sexual abuse } \\
\text { before and after } \\
\text { age } 13\end{array}$ & $-0.27(0.06)^{* *}$ & $-0.29(0.06)^{* *}$ & $-0.33(0.07)^{* *}$ & $-0.31(0.12)^{* *}$ \\
\hline Gender (girl = 1) & & $0.14(0.04)^{* *}$ & & \\
\hline $\begin{array}{l}\text { One or both } \\
\text { parents are } \\
\text { immigrants }\end{array}$ & & $-0.23(0.06)^{* *}$ & $-0.21(0.08)^{* *}$ & $-0.25(0.09) * *$ \\
\hline $\begin{array}{l}\text { One or both } \\
\text { parents had been } \\
\text { on welfare in the } \\
\text { past two years }\end{array}$ & & $0.10(0.06)$ & $0.21(0.08)^{* *}$ & $-0.03(0.10)$ \\
\hline $\begin{array}{l}\text { One or both } \\
\text { parents work } \\
\text { fulltime }\end{array}$ & & $0.20(0.06)^{* *}$ & $0.27(0.07)^{* *}$ & $0.09(0.09)$ \\
\hline $\begin{array}{l}\text { One or both } \\
\text { parents with } \\
\text { higher education }\end{array}$ & & $0.82(0.05)^{* *}$ & $0.90(0.07)^{* *}$ & $0.76(0.08)^{* *}$ \\
\hline $\begin{array}{c}\text { Parents are } \\
\text { together }\end{array}$ & & $0.24(0.07)^{* *}$ & $0.23(0.09)^{*}$ & $0.28(0.12)^{*}$ \\
\hline $\begin{array}{l}\text { Family economic } \\
\text { situation }\end{array}$ & & $0.11(0.03)^{* *}$ & $0.13(0.04)^{* *}$ & $0.08(0.05)$ \\
\hline $\begin{array}{l}\text { Parents own the } \\
\text { house they live } \\
\text { in }\end{array}$ & & $0.46(0.10)^{* *}$ & $0.44(0.12)^{* *}$ & $0.51(0.16)^{* *}$ \\
\hline $\mathrm{R}^{2}$ & 0.02 & 0.08 & 0.09 & 0.07 \\
\hline
\end{tabular}

Method $=$ Enter. $* p<0.05 ; * * p<0.01$

variables are controlled for both girls and boys. However, gender differences are present only for the influences of some background variables, for example, parents who receive welfare support, parents working fulltime and family economic situation. In these three areas, there is a significant impact upon girls' achievement but not boys.

Table 4 presents the results of the structural modelling. The results show that violence by parents (which is a latent construct of non-physical and physical abuse by 


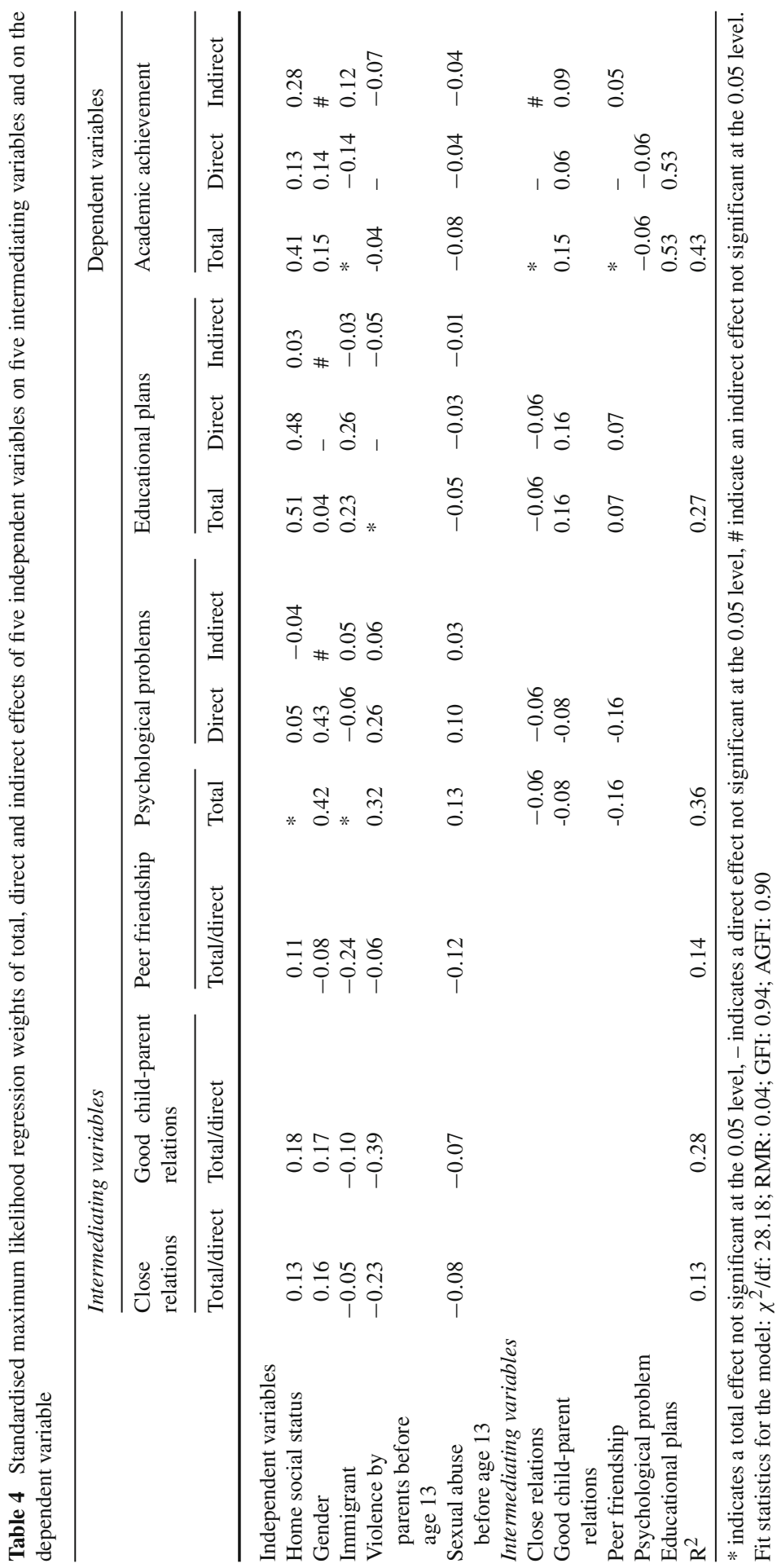


parents) before the age of 13 has a strong negative effect on close relations and good child-parent relations, but a weak negative effect on peer friendship, while sexual abuse before the age of 13 has a negative and weak but significant effect on all social capital variables. Both violence and sexual abuse which happened before the age of 13 contribute to psychological problems for the young people, which in turn negatively influences their educational plans and achievement at the same time. Violence by parents before the age of 13 does not appear to have a significant direct impact on young people's educational plans and achievement but it exerts indirect negative influences on educational outcomes by way of its negative influences on social capital and its contribution to psychological problems. Exposure to sexual abuse before the age of 13 has persistently both direct and indirect influences on educational outcomes.

Social capital is found to be significant in reducing psychological problems which are negatively associated with achievement. Good child-parent relations have a positive and significant influence on academic achievement both directly and indirectly by means of their negative effects on psychological problems and their positive influence on educational plans. Similarly, peer friendships have a positive effect on achievement by means of their significant contribution in reducing psychological problems and their positive influence on educational plans. Nevertheless, the previous sociological assumption is again evident in this case where home social status is a strong factor influencing both educational plans and the academic achievement of the young people. Social capital functions as a mediating factor not only to transmit home background influences upon educational outcomes, but also to reduce the psychological and educational damage to the young people resulting from their childhood experiences of violence.

The variances explained by the factors in the analyses in Table 4 are rather substantial. Background factors and having, or not having, experienced violence during childhood have explained $13 \%$ of the difference between low and high scores of close relations, $28 \%$ of the difference in child-parent relations and $14 \%$ of that in peer friendship. Immigrant background and violence by parents are the strongest factors influencing student social relations. Gender and exposure to abuses during childhood explain $36 \%$ of the variance between low and high scores of psychological problems. Furthermore, the model explains $27 \%$ of the variance in educational plans (plans to take or not pursue higher education) and $43 \%$ of the variance between low and high academic achievements of the young people. While exposure to abuse during childhood, especially sexual abuse, has significant negative impacts on education outcomes, home social status and ethnic backgrounds are the strongest factors.

\section{Conclusion}

This study has provided additional evidence showing the long term damage of violence and sexual abuse against children, particularly damage regarding the educational career of the young victims. First, the data show that young victims of violence and sexual abuse are slightly overrepresented among young people from families with lower social and economic status. Second, exposures to peer violence and the experience of sexual abuse have strong negative effects on achievement, while non-physical 
abuse and witness of abuse appear to have little effect when background variables are controlled. Third, childhood experience of violence by parents and sexual abuse are found to have persistent negative effects on the psychological health and educational outcomes of the child both directly and indirectly through its influence on the child's social relations. Although home social status and immigrant background are again the strongest factors directly influencing the educational career of the young people in this case, social relations, especially child-parent relations and peer friendships, can contribute significantly in reducing the psychological damage of violence experienced during childhood. These support their educational development in the long run.

The findings of this study are of particular importance not only for parenting at home but also for psychological counselling in the social work sector and for teachers in schools. First, violence against children of any kind should be strongly prevented at home, school and in society. Second, the general population, and especially parents, should be well informed of the long-term damage of any violence against children, and should be educated about factors and actions that can reduce the damage. Third, forging a good relationship between the parents and the child, and supporting the construction of friendships between the child and his/her peers, are immediate and feasible actions which parents, social workers and teachers can take to reduce the damage and prevent future violence.

In Norway children may be referred to Mental Health Services for children and adolescents (BUP) to receive counselling or therapy to lessen the impact of abuse. The referrals can be made by the family doctor or by the child protection service ('Barnevern' in Norwegian, meaning Child Welfare Service). Usually, however, it is necessary that the child displays certain symptoms to receive help from this service. Sexual abuse and its consequences still seem to be a difficult topic to deal with by professionals within the mental health system, especially if it is not confirmed by the legal system (Tjersland et al. 2006). Moreover, the child protection service in Norway is constrained by the limited legal age of a child (between ages 0-18) and by the inadequate provision of services across the country (Falck and Vorland 2009) where many children and young people do not have access to immediate help in a crisis situation. Knowing that experiences of abuse may have a serious impact on the victims such as depression, behavior problems, and PTSD (Banyard et al. 2004) where each of these symptoms may have negative effects on school performance, a more available and efficient support system, co-operating with schools, would be a good preventive strategy to avoid early school leaving and to improve academic performance.

Although the data in this study have been rather comprehensive as to the inclusion of background information and detailed accounts of the experiences of the young people, the interpretation of the data is somewhat hampered by the fact that the correspondents were aged 18-19 when they were asked to recall their experiences before and after the age of 13. Nevertheless, data shortage and access to informants have long been the problem in studying victims of violence at a younger age. Greater efforts by academic research are clearly needed to better inform social workers and the relevant authorities regarding the severity of violence against children in our society, and the long term psychological damage of violence which is reflected in the hampered social and educational development of children, even in an affluent society such as Norway. 
More common actions by relevant social institutions are needed to prevent and to heal the damage of violence against children.

Acknowledgements This work was supported by research institute of NOVA- Norwegian Social Research and the Ministry of Children, Equality and Social Inclusion.

Open Access This article is distributed under the terms of the Creative Commons Attribution Noncommercial License which permits any noncommercial use, distribution, and reproduction in any medium, provided the original author(s) and source are credited.

\section{References}

Astone, N. M., Constance, A. N., Schoen, R., \& Kim, Y. J. (1999). Family demography, social theory, and investment in social capital. Population and Development Review 25, 1-31

Banyard, V. L., Williams, L. M., \& Siegel, J. A. (2004). Childhood sexual abuse: A gender perspective on context and consequences. Child Maltreatment, 9(3), 223-238.

Boden, J. M., Horwood, L. J., \& Fergusson, D. M. (2007). Exposure to childhood sexual and physical abuse and subsequent educational achievement outcomes. Child Abuse \& Neglect, 31, 1101-1114.

Breen, R., \& Jonsson, J. O. (2005). Inequality of opportunity in comparative perspective: Recent research on educational attainment and social mobility. Annual Review of Sociology, 31, 223-243.

Buru-Bellat, M. (2004). Social inequality at school and educational policy. Fundamentals of educational planning. Paris: IIEP, UNESCO.

Cicchetti, D., \& Toth, S. L. (2005). Child maltreatment. Annual Review of Clinical Psychology, 1, 409-438.

Coleman, J. (1988). Social capital in the creation of human capital. American Journal of Sociology, 94, 94-120.

Constantinos, M., Kokkinos, M., \& Panayiotou, G. (2007). Parental discipline practices and locus of control: Relationship to bullying and victimization experiences of elementary school students. Social Psychology of Education, 10(3), 281-301.

Daignault, I. V., \& Hebert, M. (2004). The school adaptation of sexually abused children. Canadian Psychology, 45(4), 293-307.

Desjardins, R. (2003). Determinants of economic and social outcomes from a life-wide learning perspective in Canada. Education Economics, 11, 11-38.

Downes, P. (2008). Mental health strategy for deprived children missing from education plan in Action on Poverty Today, 21. Combat Poverty Agency: Dublin.

Downes, P. (2010). It's the heart stupid. Emerging priority issues for prevention of early school leaving: A solution-focused approach. Presentation to the Belgian EU presidency conference Breaking the cycle of disadvantage-social inclusion in and through education. 28-29 September 2010. Ghent, Belgium.

Erikson, R., \& Jonsson, J. O. (1998). Social origin as an interest-bearing asset: Family background and labour-market rewards among employees in Sweden. Stockholm: Swedish Institute for Social Research, Stockholm University.

Falck, S., \& Vorland, N. (2009). Problems don't have office hours: The Norwegian emergency child welfare services. NOVA Rapport, 5/09. Oslo: NOVA. Available http://www.nova.no/asset/3742/1/ 3742_1.pdf (in Norwegian with English summary).

Fergusson, D. M., \& Mullen, P. E. (1999). Childhood sexual abuse-an evidence based perspective. Thousand Oaks: Sage, CA.

Fromm, S. (2001). Total estimated cost of child abuse and neglect in the United States: Statistical evidence. Chicago, IL: Prevent Child Abuse America (PCAA). Available at: <http://member.preventchildabuse. org/site/PageServer?pagename=research_reports_and_surveys $>$. Accessed 10 Nov 2010.

Georgiou, S. N., \& Fanti, K. A. (2010). Did you mean 'mistreatment' rather than 'maltreatment'? A transactional model of bullying and victimisation. Social Psychology of Education, 13(3), 295-311.

Gilbert, R., Widom, C. S., Browne, K., Fergusson, D., Webb, E., \& Janson, S. (2009). Burden and consequences of child maltreatment in high-income countries. The Lancet, 373(9657), 68-81. 
Güzel, C. I., \& Berberoglu, G. (2005). An analysis of the programme for international student assessment 2000 (PISA 2000) mathematical literacy data for Brazilian, Japanese and Norwegian students. Studies in Educational Evaluation, 31, 283-314.

Hjemdal, O., Briborg, O., Stiles, T. C., Martinussen, M., \& Rosenvinge, J. H. (2006). A new scale for adolescent resilience: Grasping the central protective resources behind healthy development. Measurement and Evaluation in Counseling and Development, 39, 84-96.

Hoyle, R. H., \& Pantere, A. T. (1995). Writing about structural equations models. In R. H. Hoyle (Ed.), Structural equation modelling: Concepts, issues, and applications (pp. 158-176). London: Sage Publications.

Huang, L. (2008). How different are they? Students receiving learning assitance in the classroom in Norwegian secondary schools. In: D. M. McInercey, \& A. D. Liem (Eds.), Teaching and learning: International best practice (pp. 331-348). Greenwich: Information Age Press.

Huang, L. (2009). Social capital and student achievement in Norwegian secondary schools. Learning and Individual Differences, 19(2), 320-325.

Huang, L. (2010). Peer relations and student achievement in Norwegian secondary schools. The International Journal of Learning, 16(12), 295-306.

Husén, T. (1989). Higher education and social stratification: An international comparative study. Paris: IIEP, UNESCO.

Jöreskog, K. G., \& Sörbom, D. (1993). LISREL 8: Users' reference guide. Chicago: Scientific Software.

Kawachi, I., \& Subramanian, S. V. (2006). Measuring and modelling the social and geographic context of trauma: A multilevel modelling approach. Journal of Traumatic Stress, 19(2), 195-203.

Kjellgren, C., Priebe, G., Svedin, C. G., Mossige, S., \& Långström, N. (2009). Female Youth who sexually coerce: Prevalence, risks and protective factors in two national high school surveys. The Journal of Sexual Medicice. doi:10.1111/j.1743-6109.2009.01495.x.

Lee, V. E., \& Burkam, D. T. (2003). Dropping out of high school: The role of school organisation and structure. American Educational Research Journal, 40(2), 353-393.

Macmillan, R. (2001). Violence and the life course: The consequences of victimisation for personal and social development. Annual Review of Sociology, 27, 1-22.

Markussen, E., Frøseth, M. W., Lødding, B., \& Sandberg, N. (2008). Bortvalg og kompetanse (Dropout and competence). Rapport 13/2008. Oslo: NIFU-STEP.

Meier, A. (1999). Social capital and academic achievement among adolescents. Working Paper 99-18. University of Wisconsin-Madison: Center for Demography and Ecology.

Mossige, S., Ainsaar, M., \& Svedin, C. G. (Eds). (2007). The Baltic Sea regional study on adolescents' sexuality. Oslo: Norwegian Social Research (NOVA). Available at: http://www.nova.no/asset/2812/ 1/2812_1.pdf. Accessed 10 November 2010.

Mossige, S., \& Stefansen, K. (2007). Vold og overgrep mot barn og unge: En selvrapporteringsstudie blant avgangselever i videregående skole (Violence and abuse against children and young people: A self reporting study among last year students at upper secondary schools). NOVA Rapport, 20/07. Oslo: NOVA. Available also online: http://www.nova.no/id/15705.0.

Mueller, R. O. (1996). Basic principles of structural equation modelling: An introduction to LISREL and EQS. New York: Springer.

Olsen, R. V. (2003). Student and teacher behavior. In S. Lie, P. Linnakylä, \& A. Roe (Eds.), Northern lights on PISA: Unity and diversity in the Nordic countries in PISA 2000 (pp. 113-122). Oslo: University of Oslo.

Parada, R. H. (2006). School bullying: Psychosocial determinants and effective intervention. Sydney: University of Western Sydney.

Parcel, T. L., \& Dufur, M. J. (2001). Capital at home and at school: Effects on student achievement. Social Forces, 78(3), 881-911.

Parker, G., Tupling, H., \& Brown, L. B. (1979). A parent bonding instrument. British Journal of Medical Psychology, 52, 1-10.

Pijl, S. J., \& Frostad, P. (2010). Peer acceptance and self-concept of students with disabilities in regular education. European Journal of Special Needs Education, 25(1), 93-105.

Pinheiro, P. S. (2006). World report on violence against children. Geneva: United Nations, SecretaryGeneral. Available at: http://daccess-dds-ny.un.org/doc/UNDOC/GEN/N06/491/05/PDF/N0649105. pdf?OpenElement. Accessed 10 November 2010.

Ransdell, S. (2001). Chapter 4: Discussion and implications. International Journal of Educational Research, 35, 391-395. 
Ransdell, S., Hawkins, C., \& Adams, R. (2001). Chapter 2: Models, modelling, and the design of the study. International Journal of Educational Research, 35, 365-372.

Raskauskas, J. (2010). Multiple peer victimization among elementary school students: Relations with social-emotional problems. Social Psychology of Education, 13(4), 523-539.

Sandefur, G. D., Meier, A., \& Campbell, M. (2006). Family resources, social capital and college attendance. Social Science Research, 35, 525-553.

Seto, M. C., Kjellgren, C., Priebe, G., Mossige, S., Svedin, C. G., \& Långström, N. (2010). Sexual coercion experience and sexually coercive behaviour: A population study of Swedish and Norwegian male youth. Child Maltreatment, 15(3), 219-228.

Smith, P. K., Morita, Y., Junger-Tas, J., Olweus, D., Catalano, R. F., \& Slee, P. E. (1999). The nature of school bullying: A cross-national perspective. New York: Routledge.

Stanton-Salazar, R. D., \& Dornbusch, S. M. (1995). Social capital and the reproduction of inequality: Information networks among Maxican-origin high school students. Sociology of Education, 68, $116-135$.

Teachman, J., Paasch, K., \& Carver, K. (1996). Social capital and dropping out of school early. Journal of Marriage and the Family, 58, 773-783.

Thrupp, M. (1999). Schools making a difference: Let's be realistic!. Buckingham: Open University Press.

Tjersland, O.A., Mossige, S., Gulbrandsen, W., Jensen, T., \& Reichelt, S. (2006). Helping families when child sexual abuse is suspected but not proven. Child and Family Social Work, 11, 297-306.

Trocmé, N., MacLaurin, B., Fallon, B., Daciuk, D., Tourigny, M., \& Mayer, M., et al. (2001). Canadian incidence study of reported child abuse and neglect: Final report. Ottawa, Ontario: National Clearinghouse on Family Violence/Minister of Public Works and Government Services Canada.

Tuijnman, A. C., \& Keeves, J. P. (1997). Path analysis and linear structural relations analysis. In J. P. Keeves (Ed.), Educational research methodology and measurement: An international handbook (2nd ed., pp. 621-633). Oxford: Pergamon Press and Elsevier Science.

Veltman, M. W., \& Browne, K. D. (2001). Three decades of child maltreatment research: Implications for the school years. Trauma, Violence, and Abuse, 2(3), 215-239.

Von Soest, T., Mossige, S., Stefansen, K., \& Hjemdal, O. (2010). A validation study of the Resilience Scale for Adolescents (READ). Journal of Psychopathology and Behavioural Assessment, 32(2), 215-225.

WHO (World Health Organisation). (2006). Preventing child maltreatment: A guide to taking action and generating evidence. Geneva: WHO Press. Available at: http://whqlibdoc.who.int/publications/ 2006/9241594365_eng.pdf. Accessed 10 November 2010.

WHO. (2010). Child maltreatment. Factsheet No. 150. Geneva: WHO Press. Available at: http://www. who.int/mediacentre/factsheets/fs150/en/index.html. Accessed 4 July 2011.

\section{Author Biographies}

Dr. Lihong Huang is Senior Researcher at NOVA-Norwegian Social Research. Her area of research: youth, education, European youth policies, survey research in comparisons of education systems and policies.

Dr. Svein Mossige is Associate Professor at Institute of Psychology, University of Oslo, and senior researcher at NOVA. He also works as a clinical psychologist. Area of research: prevalence and consequences of sexual abuse and violence against children, clinical interventions in families with suspicion of sexual abuse. 